\title{
PENGARUH STRES KERJA TERHADAP KINERJA MELALUI KEPEMIMPINAN SEBAGAI VARIABEL MEDIASI PADA KARYAWAN SEKTOR NON FORMAL DI PEKANBARU
}

\author{
Arwinence Pramadewi \\ Dosen pada Jurusan Manajemen Fakultas Ekonomi Universitas Riau \\ arwinenceice@gmail.com
}

\begin{abstract}
This research was conducted in Pekanbaru with the aim to know the effect of job stress on performance through mediation of leadership variable on non-formal sector employees. The analysis is linear regression analysis. Samples were taken as many as 100 respondents who were restricted to field workers only on construction projects. The result of research by using regression showed that job stress variable influence to performance, then leadership variable have an effect on to performance, and work stress influence to leadership. Then through the mediation of leadership variables, the effect of job stress on performance increases.
\end{abstract}

Keywords: job stress, leadership, performance

\section{PENDAHULUAN}

Kinerja merupakan faktor yang sangat penting dari hasil manajemen sumber daya manusia pada sebuah organisasi. Salah satu faktor kinerja adalah produktifitas. Setiap perusahaan sangat fokus terhadap peningkatan produktifitas, karena dengan produktifitas perusahaan dapat meningkatkan laba perusahaan. Salah satu faktor yang berpengaruh langsung pada kinerja adalah stres yang dialami karyawan (Simamora, 2008). Stres dapat diakibatkan oleh lingkungan kerja yang tidak sehat dan tidak harmoni serta beban kerja fisik maupun mental yang begitu tinggi (Tarwaka, 2011). Beban kerja yang bersifat fisik maupun non fisik serta lingkungan kerja dapat merupakan stressor atau penyebab terjadinya stres terhadap karyawan. Beban kerja yang terlalu tinggi dapat mengakibatkan stres atau overstress, dan sedangkan beban kerja yang terlalu sedikit mengakibatkan karyawan banyak menganggur dan dapat juga menyebabkan stres atau understress. Maka dari itu perusahaan harus tepat dalam memberikan beban kerja kepada karyawan baik dari segi kuantitas maupun kualitas.

Selain beban kerja dan sifat pekerjaan serta kebijakan perusahaan, adapun faktor motivasi yaitu kepemimpinan sangat berperan dalam memberikan motivasi dan stimulasi kepada karyawan agar dapat disiplin dan bekerja lebih semangat dan lebih baik. Stres mungkin saja terjadi kepada setiap orang, hal ini bisa disebabkan oleh masalah pribadi atau juga masalah beban kerja yang meningkat serta lingkungan kerja yang tidak ergonomi dapat juga menyebabkan stres. Kondisi lingkungan kerja yang ergonomis mutlak diperlukan bagi setiap karyawan, karena hal merupakan kebutuhan dasar agar karyawan dapat terjamin keamanan, kesehatan dan kenyamanan dalam bekerja. Hal ini menjadi perhatian perusahaan dan juga sudah diatur dalan Undang-Undang Tenaga Kerja Republik Indonesia.

Berdasarkan data tahun 2014 Badan Pusat Statistik Provinsi Riau, angkatan kerja yang ada di Pekanbaru sekitar $70 \%$ merupakan karyawan pada sektor non formal. Karyawan pada sektor non formal umumnya adalah pekerja 
lapangan dimana beban fisik yang berlebihan sering terjadi seperti contoh terjadi pada tukang bangunan dan buruh bongkar muat di pelabuhan maupun di kompleks pergudangan, sementara kinerja yang dihasilkan sangat diperlukan agar perusahaan dapat memiliki produktifitas yang tinggi.

\section{TINJAUAN PUSTAKA}

Kinerja merupakan suatu fungsi dari motivasi dan kemampuan(Rivai dan Sagala, 2009:548).Untuk menyelesaikan tugas atau pekerjaan seseorang sepatutnya memiliki derajat kesediaan dan tingkat kemampuan tertentu.

Kinerja mempunyai makna yang luas, bukan hanya menyatakan sebagai hasil kerja, tetapi juga bagaimana proses kerja berlangsung. Kinerja adalah tentang melakukan pekerjaan dan hasil yang dicapai dari pekerjaan tersebut. Kinerja adalah tentang apa yang dikerjakan dan bagaimana cara mengerjakannya. Kinerja merupakan hasil pekerjaan yang mempunyai hubungan kuat dengan tujuan strategis organisasi, kepuasan konsumen dan memberikan kontribusi ekonomi (Wibowo 2011:2).

Hasibuan (2009:

mengemukakan bahwa kinerja adalah suatu hasil kerja yang dicapai seseorang dalam melaksanakan tugas tugas yang dibebankan kepadanya yang didasarkan atas kecakapan, pengalaman dan kesungguhan serta waktu.Hampir seluruh perusahaan melakukan tindakan informal atau formal dalam menilai kinerja karyawan mereka.Penilaian kinerja berarti mengevaluasi kinerja karyawan saat ini dan/ atau di masa lalu relatif terhadap standart kinerjanya.

Manajemen kinerja termasuk praktek manajer mendefinisikan tujuan dan pekerjaan karyawan, mengembangkan kemampuan karyawan, serta mengevaluasi dan memberikan penghargaan pada usaha seseorang yang keseluruhannya ada dalam kerangka bagaimana seharusnya kinerja karyawan berkontribusi untuk mencapai tujuantujuan perusahaan (Dessler, 2011:322).

Stress kerja adalah suatu kondisi ketegangan yang menciptakan adanya ketidakseimbangan fisik dan psikis, yang memengaruhi emosi, proses berpikir, dan kondisi seorang karyawan (Rivai\& Sagala, 2009:1008).Istilah ini mencakup pada kondisi tekanan, beban, konflik, keletihan, ketegangan, panik, kecemasan, kemurungan dan kehilangan daya yang dialami oleh seseorang.

Stres yang terlalu besar dapat mengancam kemampuan seorang karyawan dalam menghadapi lingkungannya. Hasilnya bisa jadi akan melahirkan rasa frustasi. Frustasi sendiri merupakan keadaan emosional, ketegangan pikiran, dan perilaku yang tidak terkendali, sehingga ia cenderung berbuat yang tidak wajar dan bisa membahayakan dirinya sendiri dan orang lain (Hasibuan, 2009:205). Pegawai yang stres bisa mengalami nervous dan merasakan kecemasan (anxiety) yang kronis apabila tidak segera mendapat penanganan.Mereka sering menjadi mudah marah, agresif, gelisah, tidak koperaratif dan pada tingkatan tertentu mereka dapat menjadi destruktif.

Pegawai yang stres bisa mengalami nervous dan merasakan kecemasan (anxiety) yang kronis apabila tidak segera mendapat penanganan.Mereka sering menjadi mudah marah, agresif, gelisah, tidak koperaratif dan pada tingkatan tertentu mereka dapat menjadi destruktif.Dalam jangka pendek, stres yang dibiarkan begitu saja tanpa penanganan serius akan membuat karyawan tertekan, tidak termotivasi, dan frustasi, sehingga pada gilirannya menyebabkan karyawan tidak bekerja optimal. Prestasi kerja pun terpengaruh. Sedangkan dalam jangka panjang, jika karyawan tidak mampu mengendalikan stresnya, maka besar 
Jurnal Ilmiah Ekonomi dan Bisnís

Vol. 15. No.1, Maret 2018: 34-41

EISSN : $2442-9813$

ISSN : $1829-9822$

kemungkinan ia tidak akan mampu lagi untuk mempertahankan pekerjaannya. Sementara pada tahap yang sangat parah, si karyawan yang bersangkutan akan terganggu kesehatan fisik dan mentalnya (Mathis \& Jackson, 2009:374).

Definisi kepemimpinan secara luas meliputi proses memengaruhi dan menentukan tujuan organisasi, memotivasi perilaku pengikut untuk mencapai tujuan, memengaruhi untuk memperbaiki kelompok dan budaya nya. Kepemimpinan terkadang dipahami sebagai kekuatan untuk menggerakkan dan memengaruhi orang. Kepemimpinan sebagai sebuah alat, sarana atau proses untuk membujuk orang agar bersedia melakukan sesuatu secara sukarela/sukacita. Kepemimpinan juga dikatakan sebagai proses mengarahkan dan memengaruhi aktivitas-aktivitas yang ada hubungannya dengan pekerjaan para anggota kelompok (Rivai dan Mulyadi, 2011:2).Menurut Robbins dan Judge (2008:49), kepemimpinan (leadership) sebagai kemampuan untuk memengaruhi suatu kelompok guna mencapai sebuah visi atau serangkaian tujuan yang ditetapkan.Sumber pengaruh ini bisa jadi bersifat formal, seperti yang diberikan oleh pemangku jabatan manajerial dalam sebuah organisasi.Atau juga bersifat informal berupa kharisma dan kewibawaan yang dimiliki oleh seorang pimpinan.

Manajemen yang baik menghasilkan keteraturan dan konsistensi dengan cara mempersiapkan rencana formal, merancang struktur organisasi yang kuat, dan monitor hasil berdasarkan rencana. Sebaliknya, kepemimpinan berkaitan dengan perubahan. Pemimpin menentukan arah dengan cara mengembangkan suatu visi masa depan, kemudian, mereka menyatukan orang-orang dengan mengkomunikasikan visi ini dan menginspirasi mereka untuk mengatasi berbagai rintangan (Robins dan Judge 2008:48).

Usaha mempelajari kepemimpinan pada mulanya dilakukan pada tahun 1930 oleh Ronald Lipit dan Ralph K. White di bawah pengarahan dari Kurt Lewindi Universitas Iowa Amerika Serikat. Dari studi ini diperoleh tiga gaya (style) kepemimpinan yaitu (Thoha, 2010:275):Otokratis: bertindak sangat direktif, selalu memberikan pengarahan, dan tidak memberikan kesempatan timbulnya partisipasi. Pimpinan seperti ini suka memberikan perhatian yang individual dalam memuji atau memberikan kritikan.Demokratis: mendorong kelompok diskusi dalam membuat keputusan. Pimpinan berusaha obyektif di dalam memberikan pujian dan kritik.Laissez Faire: santai, memberikan kebebasan mutlak kepada kelompok, sehingga pada hakikatnya tipe ini kurang memberikan contoh kepemimpinan yang ideal.

Gaya kepemimpinan adalah pola menyeluruh dari tindakan seorang pemimpin, baik yang tampak maupun yang tidak tampak oleh bawahan.Gaya kepemimpinan menggambarkan kombinasi yang konsisten dari falsafah, keterampilan, sifat, dan sikap yang mendasari perilaku seseorang.Gaya kepemimpinan yang menunjukkan, secara langsung maupun tidak langsung, tentang keyakinan seorang pemimpin terhadap kemampuan bawahannya. Artinya, kepemimpinan adalah perilaku dari strategi, sebagai hasil kombinasi dan falsafah, keterampilan, sifat, sikap, yang sering diterapkan seorang pemimpin ketika ia mencoba memengaruhi kinerja bawahannya. Sehingga gaya kepemimpinan yang paling tepat adalah suatu gaya yang memaksimumkan produktivitas, kepuasan kerja, pertumbuhan, dan mudah menyesuaikan dalam segala situasi. Gaya kepemimpinan merupakan dasar dalam mengklasifikasikan kepemimpinan. 


\section{METODE PENELITIAN}

Penelitian dilakukan pada pekerja sektor non formal, disini peneliti membatasi pada pekerja atau karyawan yang bekerja pada proyek konstruksi yang ada di kota Pekanbaru.

Dalam penelitian ini diperlukan data, baik berupa data primer maupun data sekunder, yaitu akan dijelaskan sebagai berikut : Data Primer. Merupakan data yang diperoleh secara langsung yang berasal dari sumbernya, yaitu data yang diperoleh langsung dari responden. Data Sekunder, merupakan sumber data penelitian yang diperoleh secara tidak langsung dari sumbernya tetapi melalui media perantara. Seperti buku-buku literatur, surat kabar, majalah, perusahaan, instansi dan informasi yang berhubungan dengan masalah yang sedang diteliti.

Populasi penelitian adalah seluruh pekerja atau karyawan sektor non formal yang bekerja pada lepas pada proyek konstruksi di kota Pekanbaru. Oleh karena jumlah keseluruhan populasi tidak diketahui, maka penelitia melakukan quoting sejumlah 100 pekerja sektor non formal untuk dijadikan sampel.(Sugiyono, 2013)

Pengumpulan data yang digunakan dalam penelitian ini melalui: kuesioner dan wawancara. Penelitian ini dilakukan dengan membagikan kuesioner kepada pelanggan yang mempunyai hubungan dengan permasalahan yang akan dibahas dalam penelitian ini disertai wawancara kepada pelanggan. Penelitian pustaka, penelitian pustaka adalah penelitian yang dilakukan dalam upaya memperoleh bahan-bahan berupa teori melalui kajian buku-buku literatur, bahan kuliah dan karangan ilmiah lainnya sebagai landasan teori. Teknik analisis data dengan menggunakan teknik kuantitif

\section{HASIL DAN PEMBAHASAN}

Analisis regresi linier berganda ini digunakan untuk mengetahui ada tidaknya pengaruh dari variabel bebas terhadap variabel terikat, yaitu mencari pengaruh variabel bebas (independentvariable) terhadap variabel terikat (dependentvariable). Berikut adalah hasil analisis regresi linear berganda dimana data ordinal kemudian diolah menggunakan SPSS versi 20.0 :

\section{Tabel 1: Analisis Regresi Coefficients $^{\mathrm{a}}$}

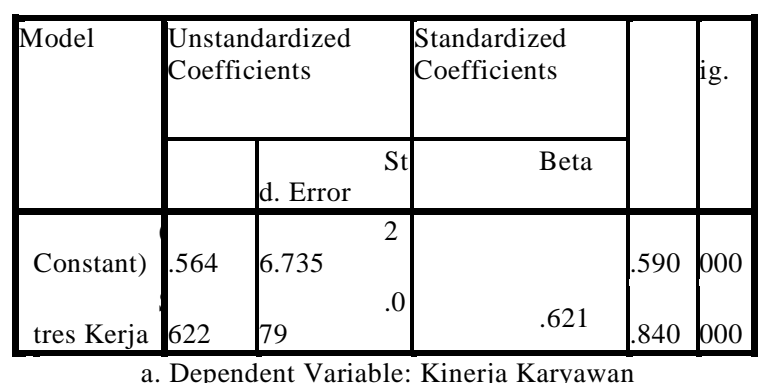

Sumber: Data Olahan SPSS Versi 21.0 Tahun 2015

Berdasarkan tabel diatas, maka didapatkan rumus regresi sebagai berikut:

$\mathrm{Y} 2=\mathbf{2 , 5 6 4}+\mathbf{0 , 6 2 2} \mathrm{X}+\mathrm{e}$

Interpretasi dari regresi diatas adalah sebagai berikut:

a. Konstanta (a)

Ini berarti jika semua variabel bebas memiliki nilai nol (0) maka nilai variabel terikat (Y2) yaitu Kinerja Karyawan bernilai 256,388.

b. Variabel bebas (X) terhadap Variabel terikat (Y2)

Sebagai contoh $\mathrm{Ni}$ ien variabel $X$ sebesar 0,622 , Hal ini mengandung arti bahwa setiap kenaikan Stres Kerja $(X)$ satu satuan maka variabel Kinerja (Y2) akan naik sebesar 0,622.

2. Uji T (Uji Parsial)

Uji hipotesis dilakukan untuk mengetahui ada tidaknya pengaruh variable bebas dengan variable terikat secara parsial. Untuk mengetahui apakah hipotesa yang diajukan adalah signifikan atau tidak, maka perlu membandingkan 


\section{Jurnal Ilmiah Ekonomi dan Bisnis}

Vol. 15. No.1, Maret 2018: 34-41

EISSN : $2442-9813$

ISSN : $1829-9822$

antara thitung dengan $t$ tabel. Di mana jika nilai $\mathrm{t}$ hitung $>\mathrm{t}$ tabel , maka hipotesa dapat diterima, dan sebaliknya, jika $\mathrm{t}$ hitung $<\mathrm{t}$ tabel maka hipotesis 1 diatas tidak dapat diterima. Diketahui bahwa t tabel untuk df $=100-1=99$ dengan signifikasi 5\% adalah 1,990.

Pada tabel 4.10 di atas terlihat nilai t hitung Stres Kerja (X) adalah 7,84 , hal ini berarti lebih besar dari t tabel, kemudian nilai sig adalah 0,000 lebih kecil dari taraf 0,05 , maka dari hipotesis dapat diterima berarti terdapat pengaruh yang signifikan dari Stres Kerja (X) terhadap Kinerja.

Untuk mengetahui sejauhmana pengaruh dari variabel bebas terhadap variabel terikat, maka pada tabel di bawah ini dapat dilihat seberapa besar kontribusinya melalui koefisien determinasi ( $R$ square) sebagai berikut:

Tabel 3: Adjusted R Square (Koefisien Determinasi)

Model Summary ${ }^{\mathrm{b}}$

\begin{tabular}{|l|l|l|lr|l|}
\hline \multirow{2}{*}{ odel } & & Square & \multicolumn{2}{|c|}{$\begin{array}{l}\text { Adj } \\
\text { Square }\end{array}$} & $\begin{array}{l}\text { Std. } \\
\text { Rqror of the } \\
\text { Estimate }\end{array}$ \\
\hline & $621^{\mathrm{a}}$ & 385 & 9 & .37 & \multicolumn{2}{|c}{9.907} \\
\hline
\end{tabular}

a. Predictors: (Constant), Stres Kerja

b.Dependent Variable: Kinerja Karyawan

Sumber: Data Olahan SPSS Versi 21.0 Tahun 2015

Berdasarkan Tabel "Model Summary" dapat disimpulkan bahwa variabel bebas berpengaruh sebesar 38,5 $\%$ terhadap kinerja karyawan.

Analisis regresi linier berganda ini digunakan untuk mengetahui ada tidaknya pengaruh dari variabel bebas terhadap variabel terikat, yaitu mencari pengaruh variabel bebas (independentvariable) terhadap variabel terikat (dependentvariable). Berikut adalah hasil analisis regresi linear berganda dimana data ordinal kemudian diolah menggunakan SPSS versi 20.0 :
Tabel 3: Analisis Regresi Coefficients $^{\mathrm{a}}$

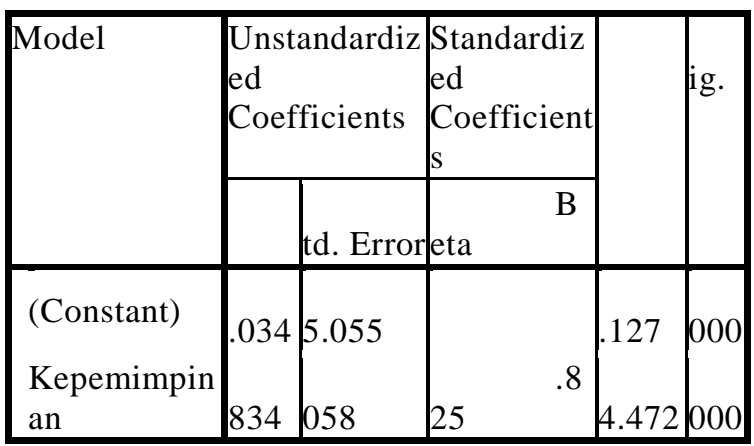

a. Dependent Variable: Kinerja Karyawan

Sumber: Data Olahan SPSS Versi 21.0 Tahun 2015

Berdasarkan tabel diatas, maka didapatkan rumus regresi sebagai berikut:

$\mathrm{Y} 2=1,034+0,834 \mathrm{Y} 1+\mathrm{e}$

Interpretasi dari regresi diatas adalah sebagai berikut:

a. Konstanta (a)

Ini berarti jika semua variabel bebas memiliki nilai nol (0) maka nilai variabel terikat (Y2) yaitu Kinerja Karyawan bernilai 103,413.

b. Variabel bebas (Y1) terhadap Variabel terikat (Y2)

Sebagai contoh Nilai koefisien variabel Y1 sebesar 0,834, Hal ini mengandung arti bahwa setiap kenaikan Kepemimpinan (Y1) satu satuan maka variabel Kinerja (Y2) akan naik sebesar 0,834 .

Uji hipotesis dilakukan untuk mengetahui ada tidaknya pengaruh variable bebas dengan variable terikat secara parsial. Untuk mengetahui apakah hipotesa yang diajukan adalah signifikan atau tidak, maka perlu membandingkan antara thitung dengan $\mathrm{t}$ tabel. Di mana jika nilai $\mathrm{t}$ hitung $>\mathrm{t}$ tabel, maka hipotesa dapat diterima, dan sebaliknya, jika $t$ hitung $<\mathrm{t}$ tabel maka hipotesis 1 diatas tidak dapat diterima. Diketahui bahwa $t$ tabel untuk df $=100-1=99$ dengan signifikasi $5 \%$ adalah 1,990.

Pada tabel 4.10 di atas terlihat nilai $\mathrm{t}$ hitung Kepemimpinan (Y1) adalah 14,472 , hal ini berarti lebih besar dari $\mathrm{t}$ 
tabel, kemudian nilai sig adalah 0,000 lebih kecil dari taraf 0,05, maka dari hipotesis dapat diterima berarti terdapat pengaruh yang signifikan dari Kepemimpinan (Y1) terhadap Kinerja (Y2).

Untuk mengetahui sejauhmana pengaruh dari variabel bebas terhadap variabel terikat, maka pada tabel di bawah ini dapat dilihat seberapa besar kontribusinya melalui koefisien determinasi ( $R$ square) sebagai berikut:

Tabel 4: Adjusted R Square (Koefisien Determinasi)

Model Summary ${ }^{b}$

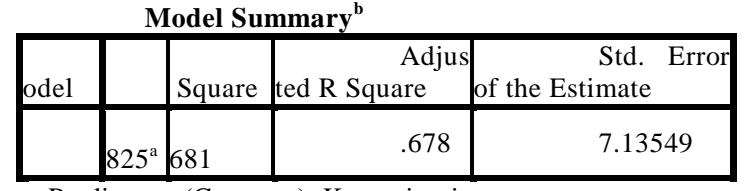

a. Predictors: (Constant), Kepemimpinan

b. Dependent Variable: Kinerja Karyawan

Sumber: Data Olahan SPSS Versi 21.0 Tahun 2015

Berdasarkan Tabel "Model Summary" dapat disimpulkan bahwa variabel bebas berpengaruh sebesar 68,1 $\%$ terhadap kinerja karyawan.

Analisis regresi linier berganda ini digunakan untuk mengetahui ada tidaknya pengaruh dari variabel bebas terhadap variabel terikat, yaitu mencari pengaruh variabel bebas (independentvariable) terhadap variabel terikat (dependentvariable). Berikut adalah hasil analisis regresi linear berganda dimana data ordinal kemudian diolah menggunakan SPSS versi 20.0 :

Tabel 5: Analisis Regresi

Coefficients $^{\mathrm{a}}$

\begin{tabular}{|c|c|c|c|c|c|}
\hline \multirow[t]{2}{*}{ Model } & \multicolumn{2}{|c|}{$\begin{array}{l}\text { Unstandardized } \\
\text { Coefficients }\end{array}$} & \multirow{2}{*}{\begin{tabular}{|r}
$\begin{array}{l}\text { Standardized } \\
\text { Coefficients }\end{array}$ \\
Beta
\end{tabular}} & & \multirow[t]{2}{*}{ ig. } \\
\hline & & td. Error & & & \\
\hline (Constant) & .767 & 1.434 & & .242 & 000 \\
\hline tres Kerja & 767 & 064 & .773 & 2.052 & 000 \\
\hline
\end{tabular}

Sumber: Data Olahan SPSS Versi 21.0

Tahun 2015
Berdasarkan tabel diatas, maka didapatkan rumus regresi sebagai berikut:

$\mathrm{Y} 1=1,767+0,767 \mathrm{X}+\mathrm{e}$

Interpretasi dari regresi diatas adalah sebagai berikut:

c. Konstanta (a)

Ini berarti jika semua variabel bebas memiliki nilai nol (0) maka nilai variabel terikat (Y1) yaitu Kepemimpinan bernilai 1,767 .

d. Variabel bebas (X) terhadap Variabel terikat (Y1)

Sebagai contoh Nilai koefisien variabel $X$ sebesar 0,767, Hal ini mengandung arti bahwa setiap kenaikan Stres Kerja (X) satu satuan maka variabel Kepemimpinan (Y1) akan naik sebesar 0,767 .

Uji hipotesis dilakukan untuk mengetahui ada tidaknya pengaruh variable bebas dengan variable terikat secara parsial. Untuk mengetahui apakah hipotesa yang diajukan adalah signifikan atau tidak, maka perlu membandingkan antara thitung dengan $t$ tabel. Di mana jika nilai $\mathrm{t}$ hitung $>\mathrm{t}$ tabel, maka hipotesa dapat diterima, dan sebaliknya, jika $t$ hitung $<\mathrm{t}$ tabel maka hipotesis 1 diatas tidak dapat diterima. Diketahui bahwa $\mathrm{t}$ tabel untuk df $=100-1=99$ dengan signifikasi $5 \%$ adalah 1,990 .

Pada tabel 4.14 di atas terlihat nilai t hitung Stres Kerja (X) adalah 12.052, hal ini berarti lebih besar dari t tabel, kemudian nilai sig adalah 0,000 lebih kecil dari taraf 0,05, maka dari hipotesis dapat diterima berarti terdapat pengaruh yang signifikan dari Stres Kerja (X) terhadap Kepemimpinan (Y1).

$$
\text { Untuk mengetahui }
$$
sejauhmana pengaruh dari variabel bebas terhadap variabel terikat, maka pada tabel di bawah ini dapat dilihat seberapa besar kontribusinya melalui koefisien determinasi ( $R$ square) sebagai berikut: 
Jurnal Ilmiah Ekonomi dan Bisnis

Vol. 15. No.1, Maret 2018: 34-41

EISSN : 2442 - 9813

ISSN : 1829-9822

Tabel 6: Adjusted R Square (Koefisien Determinasi)

Model Summary ${ }^{b}$

\begin{tabular}{|l|l|l|lr|lr|}
\hline odel & & Square & \multicolumn{2}{|c|}{$\begin{array}{r}\text { Adjed } \\
\text { Square }\end{array}$} & $\begin{array}{r}\text { Std. } \\
\text { R }\end{array}$ & $\begin{array}{l}\text { Error of } \\
\text { Estimate }\end{array}$ \\
\hline & $773^{\mathrm{a}}$ & 597 & 3 & .59 & \multicolumn{2}{|c|}{7.942} \\
\hline
\end{tabular}

a. Predictors: (Constant), Stres Kerja

b. Dependent Variable: Kepemimpinan

Sumber: Data Olahan SPSS Versi 21.0 Tahun 2015

Berdasarkan Tabel "Model Summary" dapat disimpulkan bahwa variabel bebas berpengaruh sebesar 59,7 $\%$ terhadap kepemimpinan.

Hasil analisis di atas menunjukan bahwa setiap variabel bebas memberikan pengaruh terhadap variabel terikat, yaitu variabel stres kerja memberikan pengaruh terhadap kinerja karyawan, kemudian variabel kepemimpinan memberikan pengaruh terhadap variabel kinerja karyawan hal ini berarti kepemimpinan dapat dijadikan variabel mediasi antara stres kerja dan kinerja karyawan. Kemudian variabel stres kerja sendiri memberikan pengaruh terhadap kepemimpinan, maka dari itu pengaruh setiap variabel melalui mediasi dapat dilihat pada gambar berikut:

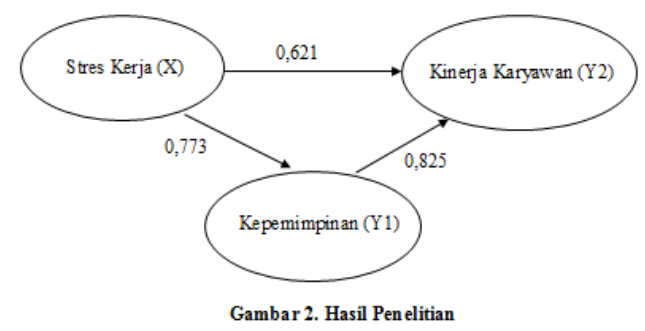

Dari gambar di atas dapat dilihat bahwa stres kerja (X) dapat memberikan pengaruh langsung terhadap kinerja karyawan (Y2). Kemudian Kepemimpinan (Y1) juga dapat memberikan pengaruh langsung terhadap kinerja karyawan (Y2) serta kepemimpinan dapat menjadi mediasi yang dapat memperkuat pengaruh stress kerja terhadap kinerja karyawan dengan $0,773 * 0,825>0,621$.

\section{KESIMPULAN DAN SARAN}

Hasil analisis dan pembahasan dapat menjawab permasalahan dalam penelitian ini, sehingga dapat disimpulkan bahwa: Terdapat pengaruh stres kerja terhadap kinerja pada karyawan sektor non formal di Pekanbaru. Terdapat pengaruh kepemimpinan terhadap kinerja pada karyawan sektor non formal di pekanbaru. Variabel kepemimpinan dapat berperan sebagai variabel mediasi yang dapat meningkatkan pengaruh stres kerja terhadap kinerja karyawan.

Berdasarkan kesimpulan dan telaah pustaka pada penelitian ini maka saran yang dapat diberikan adalah sebagai berikut: Perusahaan yang mempekerjakan pekerja lepas atau non formal, terutama yang bekerja di lapangan dimana beban dan resiko cukup tinggi menciptakan stres kerja dapat lebih meningkatkan kepemimpinan dalam memimpin suatu tim, agar kinerja dapat lebih baik. Perusahaan pemberi kerja agar lebih dapat memberikan rasa aman serta arahan dan motivasi kepada pekerja sektor non formal terutama yang bekerja pada lingkungan yang beresiko. Bagi peneliti selanjutnya dapat meningkatkan penelitian ini dengan meneliti pengaruh variabel lain terhadap kinerja.

\section{DAFTAR PUSTAKA}

Ariwibowo, R. Novianto, 2011. Pengaruh Kepemimpinan, Motivasi dan Lingkungan Kerja Fisik Terhadap Kinerja Karyawan

Bass, BM.2009. Leadership and Performance Beyaond Expectation. New York: Free Press.

Brealey, Erica, 2010. Ten Minute Stress. Cassell Publisher, London, UK

Covey, S.P. 2009. The Seven Habits of Highly Effective People, New York: Somon \& Schuster. 
Danim, Sudarwan, 2009. Motivasi, Kepemimpinan dan Efektivitas Kelompok Penerbit Rineka Cipta, Jakarta

Dessler, Gary, 2011. Manajemen Sumber Daya Manusia. Salemba Empat, Jakarta

Eisenbach, $R$. 2009. Transformational Leadership in the context of Organizational Change. New York:Journal of Management.

Hasibuan, Malayu, 2009. Manajemen Sumber Daya Manusia. PT Bumi Aksara, Jakarta.

Indriyani, Azazah, 2009. Pengaruh Konflik Peran dan Stres Kerja Terhadap Kinerja Perawat Wanita Rumah Sakit (Studi Pada RS Roemani Muhammadiyah Semarang)

Istijanto, 2008.Riset Sumber Daya Manusia: $\quad$ Cara Praktis Mendeteksi Dimensi-Dimensi Kerja Karyawan. Gramedia Pustaka Utama, Jakarta

Mangkunegara, Anwar Prabu, 2009. Manajemen Sumber Daya Manusia Perusahaan. RemajaRosda Karya, Bandung

Mathis, Robert L, dan John H Jackson, 2009. Manajemen Sumber Daya Manusia. Penerbit Salemba Empat, Jakarta.

Nurhendar, Siti, 2009.Pengaruh Stres Kerja dan Semangat Kerja Terhadap Kinerja Karyawan Bagian Produksi CV Aneka Ilmu Semarang

Rivai, Veithzal, dan D Mulyadi, 2011. Kepemimpinan dan Perilaku
Organisasi.PT.

Raja Grafindo

Persada, Jakarta

Rivai, Veithzal\& Ella Jauvani Sagala, 2009.Manajemen Sumber Daya Manusia Untuk Perusahaan-Dari Teori Ke Praktik, PT. Raja Grafindo Persada, Jakarta.

Robbins, Stephen \& T.A. Judge, 2008.Perilaku Organisasi. Salemba Empat, Jakarta

Simamora, Henry, 2009.Manajemen Sumber Daya Manusia, Penerbitan Sekolah Tinggi Ilmu ekonomi YKPN, cetakan ketiga,Yogyakarta

Siswanto, 2010.Dasar-Dasar Organisasi\& Manajemen, Penerbit Ghalia Indonesia, Jakarta.

Sugiyono. 2013. Statistika Untuk Penelitian. Bandung. Penerbit Alfabeta.

Thoha, Miftah, 2010. Perilaku Organisasi: Konsep Dasar dan Aplikasinya. Rajawali Press, Jakarta.

Umar, Husein, 2008. Desain Penelitian MSDM Dan Perilaku Karyawan: Paradigma Positivistik Berbasis Pemecahan Masalah. Raja Grafindo Persada, Jakarta

Wibowo, 2011.Manajemen Kinerja. Penerbit Rajawali Press, Jakarta

Winardi, 2009. Manajemen Perilaku Organisasi. Penerbit Prenada Media, Bandung.

Wiranata, Anak Agung, 2011. Pengaruh Kepemimpinan Terhadap Kinerja dan Stres Karyawan (Studi Kasus: $C V$. Mertanadi). Jurnal Ilmiah Teknik Sipil, vol. 15, No. 2, Juli 2011 